\title{
Growth, trade, and international transfers
}

\author{
Eric O'N. Fisher* \\ Department of Economics, The Ohio State University, 410 Arps Hall, 1945 North High \\ Street, Columbus, OH 43210, USA
}

\begin{abstract}
This paper analyzes the simplest neoclassical economy in which agents have finite lives and there is sustained per capita growth. The growth rate of the world economy depends upon countries' savings propensities and common technology. Trade can reverse an economy's autarkic growth trajectory, and a country with a high savings rate runs a current account surplus. If a surplus country expands aggregate demand while a deficit country contracts analogously, world growth increases. An appropriate international policy can change the path of the world economy from stagnation to growth.
\end{abstract}

Key words: Endogenous growth; Two-sector models; Overlapping generations; Current account

\section{Introduction}

The purpose of this paper is to analyze the relationship between economic growth, trade flows, and policies affecting aggregate demand in open

* I wish to thank seminar participants at the Federal Reserve Bank of Minneapolis, Cornell University, the Midwest International Economics Meetings at Michigan State, the 1992 NBER Summer Institute for International Trade and Investment, the Ohio State University, and the Tinbergen Institute at Rotterdam for comments on earlier drafts of this paper. I also thank Henry Wan and J. David Richardson for their encouragement and two anonymous referees whose comments helped improve the paper substantially. Any remaining errors are my own. 
economies. Any investigation of these phenomena must contain three elements. First, the economy under analysis must actually grow. Second, there must be some heterogeneity in the model in order to generate trade flows. And third, there must be a role for macroeconomic policy in the development process. This paper shows that international policies promote growth when they transfer wealth from countries with low savings rates to those with high rates. In essence, transferring resources from spendthrift to thrifty members of today's generation improves the welfare of all future generations.

The first piece of the puzzle involves growth. The economy described below exhibits per capita consumption growth if the world savings rate is sufficiently high. This economy has two sectors, the first producing a consumption good and the second producing an investment good. The growth rate is an increasing function of the savings rate and the marginal efficiency of investment. Since there are constant returns to scale in each sector, growth occurs only if the relative price of the investment good becomes arbitrarily small. ${ }^{1}$ Rebelo (1991) described this economy for the case of an infinitely lived agent.

The second piece involves heterogeneity. A country is a sequence of agents having similar preferences, and countries differ in three ways. They have different savings propensities, different absolute sizes, and different initial endowments of capital. In equilibrium, thrifty countries run current account surpluses and accumulate net foreign assets. Also, a capital-rich country may have an initial deficit on the capital account, owing to an outflow of investment that equalizes factor prices across countries.

The third piece of the puzzle involves cconomic policy and its affect on aggregate demand. This paper assumes that countries impose lump-sum taxes or transfers denominated in their own national fiat assets. In equilibrium, paper assets bear the same rate of return as claims against capital. ${ }^{2}$ If agents in each generation have different savings rates, there is a class of transfers that can actually turn a shrinking world economy into a growing one. A country with a current account surplus expands domestic aggregate demand, while the deficit country contracts analogously. A coordinated policy keeps paper assets from crowding out real economic investment in either country, thus promoting world growth.

There has been relatively little work in this area, although Jones and Manuelli (1990) studied trade and growth in a model with infinitely lived agents. In a classic paper, Gale (1971) first explored trade imbalances in a

\footnotetext{
${ }^{1}$ De Long and Summers (1991) showed that a low relative prices of investment goods is positively correlated with growth rates between 1960 and 1985 for a wide sample of countries.

${ }^{2}$ The model below is close in spirit to the classic one of Diamond (1965), although I allow intra-generational heterogeneity and examine equilibria that do not converge to a steady state.
} 
simple dynamic economy. Jones and Manuelli (1992) examined tax policies in a growing economy with finitely lived agents, but they focused on redistributions between agents of different generations, not different countries. In an elegant paper, Baxter (1992) examined the dynamic properties of the two-sector model, but she analyzed steady states in a model where countries are infinitely-lived agents. The literature on endogenous growth and international trade is growing rapidly (see Grossman and Helpman, 1989; Young, 1991; and Rivera-Batiz and Romer, 1991, for examples), but these authors study economies with increasing returns to scale.

\section{Summary of the results}

Although the model outlined in Section 3 seems special, it captures the asymptotic behavior of any growing convex economy with finitely lived agents, a point I emphasize in earlier work (Fisher, 1992). Such an economy's growth rate depends on only three crucial elements: labor's share in the economy, the marginal efficiency of investment, and the marginal propensity to save. The economy described below exhibits balanced growth, and the equilibrium allocations are efficient.

Section 4 examines the model for two open economies. It shows that factor-price equalization occurs in finite time. World economic growth depends upon the savings propensities in both countries, and the thrifty country acquires net foreign assets in each period. Hence surplus countries are precisely those with a higher than average asymptotic marginal propensity to save. Although I describe savings rates by specifying the agents' preferences, one can think of these parameters more generally. In particular, any long-run policy that discourages consumption and encourages savings will increase the growth rate of a closed economy. Under this more general interpretation, a surplus country is one whose policies encourage savings more than the world average.

Section 5 describes policies that increase world economic growth. These policies are lump-sum transfers between members of the same generation, and they do not crowd out real economic investment. I am tempted to call these tax-transfers monetary policy, but there is no simple dichotomy in models of overlapping generations between monetary and fiscal policy. One can think of these policies instead as profiles of national generational debt. A country runs an expansionary policy if it increases debt and suffers a concomitant worsening of external balances. My main result is that any institution inducing surplus countries to expand and deficit countries to contract enhances world growth. A system of fixed exchange rates works exactly in this way if foreign exchange flows are not sterilized. The current practice of occasional economic summits among the major industrial (G-7) 
countries serves to coordinate fiscal policies analogously. Section 6 presents brief conclusions.

\section{The model in a closed economy}

The demographic structure of the economy is that of the model of overlapping generations, with $L$ agents per generation. The 'old' agents alive at the beginning of the economy live for only one period, and each is endowed with $K_{1} / L>0$ units of capital and nothing else. Each agent in generation $t \geqslant 1$ is endowed with one unit of labor in her youth and nothing else. Each of these agents lives for two periods and saves some of her wage in order to finance consumption in old age. Since the population is constant, the development process entails per capita growth.

There are two sectors in the economy, and each is characterized by a linearly homogeneous production function. The first sector produces a rerishable consumption good, and the second produces an investment good. The production function for the consumption good is

$$
C_{t}=\left(K_{t, 1}\right)^{\theta}\left(L_{t, 1}\right)^{1-\theta},
$$

where $C_{t}$ is the output of the consumption good, $K_{t, 1}$ is the input of capital into that sector, and $L_{t, 1}$ is the input of labor into that sector, all measured at time $t$. The investment good is produced according to

$$
I_{t}=\beta K_{t, 2},
$$

where $I_{t}$ is the output of the investment good and $K_{t, 2}$ is the input of capital into that sector, both at time $t$.

Since increments to an economy's capital stock occur through investment, the law of motion for the stock of capital is

$$
K_{t+1}=(1-\delta) K_{t}+I_{t},
$$

where $K_{t}$ is the capital stock at time $t$, and $\delta \in(0,1]$ is the depreciation rate. Investment is irreversible; hence, $K_{t+1} \geqslant(1-\delta) K_{t}$.

The economy's resource constraints are

$$
K_{t, 1}+K_{t, 2} \leqslant K_{t} \text { and } L_{t, 1} \leqslant L \text {, }
$$

which states that the supply of labor is constant.

Let $h \in H_{t}$, the index set of agents born at time $t$. Preferences are summarized by the utility functions

$$
u^{h}\left(c_{1}^{h}\right)=\log c_{1}^{h}, \quad \text { if } h \in H_{0},
$$

and 


$$
u^{h}\left(c_{t}^{h}, c_{t+1}^{h}\right)=(1-\sigma) \log c_{t}^{h}+\sigma \log c_{t+1}^{h}, \quad \text { if } h \in H_{t}, t \geqslant 1,
$$

where $c_{t}^{h}$ is agent $h$ 's consumption at time $t$. The preferences in (5) entail a savings rate that is independent of the interest rate.

Let $P_{t, i}$ be the price of good $i, W_{t}$ be the wage rate, and $R_{t}$ be the rentals rate, all at time $t$. We shall use the convention $P_{1,1} \equiv 1 ;{ }^{3}$ hence, all prices are in terms of the consumption good at time 1 . The present value of the income of $h \in H_{t}$ is

$$
Y^{h}= \begin{cases}R_{1} K_{1} / L, & \text { if } h \in H_{0}, \\ W_{t}, & \text { if } h \in H_{t}, \text { with } t \geqslant 1,\end{cases}
$$

since each member of the initial generation is endowed with $K_{1} / L$ units of capital and every other agent is endowed with one unit of labor.

Agent $h$ maximizes

$$
\begin{aligned}
& u^{h}\left(c_{1}^{h}\right) \\
& \text { s.t. } P_{1,1} c_{1}^{h}+P_{1,2} k_{1}^{h} \leqslant Y^{h}, \\
& c_{1}^{h} \geqslant 0 \text {, and }(1-\delta) K_{1} / L+k_{1}^{h} \geqslant 0, \quad \text { if } h \in H_{0},
\end{aligned}
$$

and

$$
\begin{aligned}
& u^{h}\left(c_{t}^{h}, c_{t+1}^{h}\right) \\
& \text { s.t. } P_{t, 1} c_{t}^{h}+P_{t+1,1} c_{t+1}^{h}+\left(P_{t, 2}-R_{t+1}\right) k_{t}^{h}+P_{t+1,2} k_{t+1}^{h} \leqslant Y^{h}, \\
& \left(c_{t}^{h}, c_{t+1}^{h}\right) \geqslant(0,0) \text {, and }(1-\delta) k_{t}^{h}+k_{t+1}^{h} \geqslant 0, \quad \text { if } h \in H_{t}, t \geqslant 1,
\end{aligned}
$$

where $k_{t}^{h}$ is $h$ 's demand for capital at time $t$ and the inequalities represent a present-value budget constraint. The term $\left(P_{t, 2}-R_{t+1}\right)$ reflects the fact that agent $h \in H_{t}$ rents out his capital before it depreciates in period $t+1$. If $k_{t+1}^{h}<0$, then agent $h \in H_{t}$ sells capital in the second period of her life, the situation one might expect when claims on capital serve as stores of value.

Firm $i \in\{1,2\}$ chooses $K_{t, i} \geqslant 0$ and $L_{t, i} \geqslant 0$ to maximize

$$
P_{t, i} Q_{t, i}-W_{t} L_{t, i}-R_{t} K_{t, i} \text {. }
$$

Since production functions (1) and (2) are linearly homogeneous, firm i's profits at time $t$ are zero. Hence the solution to (7) maximizes the present value of a firm's equity. Since labor is not an input in (2), $L_{t, 2}=0$.

\footnotetext{
${ }^{3}$ Since there are two goods in this economy, there is no simple definition of the real interest rate. The ratio $P_{t, i} / P_{t+1, i}$ is commodity $i$ 's gross own rate of return, and a commodity has a positive rate of return if its present price is shrinking. The law of motion for capital implies that its gross own rate of return is $1+\beta-\delta$, which is greater than unity if the marginal efficiency of investment is sufficiently high.
} 
An equilibrium is a sequence of prices and aggregate quantities

$$
\left\{\left(P_{t, 1}, P_{t, 2}, W_{t}, R_{t}\right)\right\}_{t=1}^{\infty} \text { and }\left\{\left(C_{t}, I_{t}\right)\right\}_{t=1}^{\infty}
$$

such that for each $t$

(i) consumer $h \in H_{t-1} \cup H_{t}$ solves (6);

(ii) firm $i \in\{1,2\}$ solves (7);

(iii) $\sum_{h \in H_{t-1}} c_{t}^{h}+\sum_{h \in H_{t}} c_{t}^{h} \leqslant C_{t}$;

(iv) resource constraints (4) are satisfied;

(v) $K_{t+1}$ evolves according to (3); and

(vi) $K_{1}>0$ is given.

Condition (i) expresses utility maximization, (ii) profit maximization, (iii) the materials balances condition, (iv) the full employment constraints, (v) the trajectory of the capital stock, and (vi) the initial condition.

If $Q_{i, 1}>0$, profit maximization implies that

$$
R_{t}=P_{t, 1} \theta\left(k_{t, 1}\right)^{\theta-1},
$$

where $k_{t, 1}=K_{t, 1} / L$ is the capital-labor ratio in the first sector in period $t$. Also, if $Q_{t, 1}>0$, the wage rate in period $t$ is

$$
W_{t}=P_{t, 1}(1-\theta)\left(k_{t, 1}\right)^{\theta} .
$$

Since there are $L$ workers, the economy's wage bill is $W_{t} L$.

Because of the special form of the utility function, the savings of an agent born in period $t \geqslant 1$ is $\sigma W_{t}$. As long as $P_{t, 2}>0$, the equilibrium condition in the investment goods market implies

$$
\sigma W_{t}=P_{t, 2} k_{t+1},
$$

where $k_{t+1}=K_{t+1} / L$ is the economy's capital-labor ratio at time $t+1$.

We are now in a position to describe the trajectory of the economy. Define the gross marginal efficiency of investment $\Gamma \equiv 1-\delta+\beta$, and let $G \equiv k_{t+1} / k_{t}$ be the gross rate of growth of the capital stock along a balanced growth path. Then simple algebra as in Rebelo (1991) shows that

$$
G=\max \left\{\Gamma \sigma[1-\theta][\sigma(1-\theta)+\theta]^{-1}, 1-\delta\right\} .
$$

Growth occurs only if both the marginal efficiency of investment and the marginal propensity to save are sufficiently high. Furthermore, the growth rate is independent of the initial capital stock. A large value of $K_{1} / L$ is a 'level' effect; 'growth' effects depend upon the savings rate, labor's share in the first sector, and the marginal efficiency of investment.

${ }^{4}$ Another way of expressing (v) is to state that $\Sigma_{h \in\left\{H_{t-1} \cup H_{t}\right\}} k_{t}^{h} \leqslant I_{t}$. Since $\Sigma_{h \in H_{t-1}} k_{t}^{h}=$ $-(1-\delta) K_{t}$ and $\Sigma_{h \in H_{l}} k_{t}^{n}=K_{t+1}$, this expression is equivalent to the more familiar $K_{t+1} \leqslant(1-$ 8) $K_{t}+I_{r}$. 
A convenient measure of the interest rate from period $t$ to $t+1$ is $1+i_{t+1} \equiv P_{t, 1} / P_{t+1,1}$, the relative price of consumption between those periods. Along a balanced growth path with positive investment, this rate is

$$
1+i_{t+1}=\Gamma / G^{1-\theta}
$$

for all $t+1$. Eq. (1) implies that consumption grows at the rate $G^{\theta}$. Since $G<\Gamma, 1+i_{t+1}>G^{\theta}$; hence, a balanced growth path is efficient.

In equilibrium, the consumption profile of agent $h$ born at $t \geqslant 1$ is

$$
\left(c_{t}^{h}, c_{t+1}^{h}\right)=\left((1-\sigma)\left(W_{t} / P_{t, 1}\right), \sigma\left(1+i_{t+1}\right)\left(W_{t} / P_{t, 1}\right)\right) .
$$

This completes the description of the model in a closed economy.

\section{The model with two open economies}

In keeping with the spirit of the Heckscher-Ohlin paradigm, I consider a foreign economy with an identical technology but allow the marginal propensities to save to differ between economies. I shall use the convention that an asterisk represents a variable in the foreign country; for example, $1-\sigma^{*}$ is the foreign marginal propensity to consume and $K_{1}^{*}$ is the initial stock of capital in the foreign country.

There are $L$ domestic and $L^{*}$ foreign workers; let $\mu \equiv L /\left(L+L^{*}\right)$ and $\mu^{*} \equiv L^{*} /\left(L+L^{*}\right)$ be the relative sizes of the home and foreign economies, respectively. Since the populations of both economies are constant, the model captures only the effects of relative sizes of countries, not differences in their rates of demographic growth. This is not a serious limitation because the world economy will converge to that of the closed economy with the fastest rate of population growth. Then an appropriate re-definition of the rate of depreciation of capital could be used to describe per capita growth in the world economy.

Foreign firms still have production function (1) or (2), but now the law of motion for foreign economy's capital stock is

$$
K_{t+1}^{*}=(1-\delta) K_{t}^{*}+I_{t}^{*}+Z_{t},
$$

where $I_{t}^{*}$ is foreign production of the investment good and $Z_{t}$ is imports of

\footnotetext{
${ }^{5}$ It is worth emphasizing again that this relative price is not the real interest rate in this economy. It is the gross own rate of return on consumption foregone, and $I$ use it in the arguments below to state that the equilibrium allocations are dynamically efficient. A rigorous demonstration of the dynamic efficiency of the equilibrium allocations uses two facts. First, along a balanced growth path the limiting present value of the capital stock is zero. Second the Gaussian curvature of each consumer's indifference surface evaluated at the equilibrium allocations is bounded.
} 
the investment good into the foreign economy, both at time $t$. Two comments are in order. First, the two countries face the same rates of depreciation. Second, since the investment good is traded, the rentals rate will be equalized if there is positive investment in both countries.

The law of motion for the domestic economy's capital stock is now

$$
K_{t+1}=(1-\delta) K_{t}+I_{t}-Z_{t},
$$

where $I_{t}$ is production of the investment good by domestic firms and $Z_{t}$ denotes exports of that good from the domestic economy, both at time $t$.

The foreign economy's resource constraints are

$$
K_{t, 1}^{*}+K_{t, 2}^{*} \leqslant K_{t}^{*} \text { and } L_{t, 1}^{*} \leqslant L^{*} .
$$

Labor is not mobile between countries, and the present value of an agent's wage may depend upon her location.

An equilibrium with international trade is a sequence of prices and corresponding aggregate quantities

$$
\left\{\left(P_{t, 1}, P_{t, 2}, W_{t}, R_{t}, W_{t}^{*}, R_{t}^{*}\right)\right\}_{t=1}^{\infty} \text { and }\left\{\left(C_{t}, C_{t}^{*}, I_{t}, I_{t}^{*}\right)\right\}_{t=1}^{\infty}
$$

such that for each $t$ :

(i) consumer $h \in H_{t-1} \cup H_{t}$ solves (6);

(ii) firm $i \in\{1,2\}$ solves (7), given factor prices in its own country;

(iii) $\sum_{h \in H_{t-1}} c_{t}^{h}+\sum_{h \in H_{t}} c_{t}^{h} \leqslant C_{t}+C_{t}^{*}$;

(iv) resource constraints (4) and $\left(4^{*}\right)$ are satisfied;

(v) $K_{t+1}$ follows $\left(3^{\prime}\right)$ and $K_{t+1}^{*}$ follows $\left(3^{*}\right){ }^{6}$ and

(vi) $K_{1}>0$ and $K_{1}^{*}>0$ are given.

In such an equilibrium countries will typically trade the consumption good, the investment good, and claims on capital.

The equilibrium for the international economy is that of the world economy considered as an integrated system if and only if both economies are incompletely specialized in the production of both goods or, equivalently, if factor-price equalization occurs. We will now explore the conditions ensuring factor-price equalization.

Let $\omega_{t}=W_{t} / R_{t}$ be the domestic wage-rentals ratio at time $t$. It follows from (1) that

$$
k_{t, 1}=\theta(1-\theta)^{-1} \omega_{t},
$$

where $k_{t, 1}$ is again the domestic capital-labor ratio in the first sector. Of course, the investment good is infinitely capital-intensive for any wage-

\footnotetext{
${ }^{6}$ Now the equilibrium condition for the investment good can be written as $\Sigma_{h \in\left(H_{t} \cup H_{t-1}\right)} k_{t}^{h} \leqslant$ $I_{t}+I_{t}^{*}$, which again reduces to $\left(3^{\prime}\right)$ and $\left(3^{*}\right)$, although it need not be the case that the domestic demand for capital is met by sales from domestic residents and production from domestic firms.
} 
rentals ratio since that sector uses no labor. Hence, the only non-trivial pattern of complete specialization that can occur has the capital-poor country specialized in the consumption good with the other country incompletely specialized in both goods. ${ }^{7}$ This situation will indeed occur at time $t$ if the countries have sufficiently different ratios of installed capital per worker.

Assume now that one of the countries is completely specialized. Then the country with the lower capital-labor ratio will have a higher rentals rate than its trading partner, and no investment will take place in the capital-rich country. Now consider the evolution of the world economy. If the world savings rate is sufficiently low, there will be no investment in either country, the world economy will shrink at the rate $(1-\delta)$, and the equilibrium is the trivial one with both countries staying on their autarkic no-growth paths and no trade in the world economy. Otherwise, all investment in the world economy occurs in the capital-poor country, and that country's installed capital stock per worker grows strictly more quickly than does that in its trading partner. Hence, in finite time the countries must have sufficiently similar installed capital stocks per worker so that factor-price equalization does occur. We have just demonstrated:

Proposition 1. If there is any investment at all in the world economy, then factor-price equalization will occur in finitely many periods.

Proposition 1 shows that the capital stocks per worker in each country constitute an initial condition characterizing the preliminary phase of the trajectory of the world economy. They do not affect the world economy's long-run growth rate.

Before stating the second proposition, I define two terms. First, $\tilde{k}_{t} \equiv$ $\mu k_{t}+\mu^{*} k_{t}^{*}$ is the average endowment of capital per worker in the world economy at time $t$. Second, $\tilde{\sigma} \equiv \mu \sigma+\mu^{*} \sigma^{*}$ is the average propensity to save in the world. I can now state:

Proposition 2. Let factor prices be equalized in the first period. Then there is an equilibrium with balanced growth, and the rate of growth is

$$
G=\max \left\{\Gamma \tilde{\sigma}[1-\theta][\tilde{\sigma}(1-\theta)+\theta]^{-1}, 1-\delta\right\} .
$$

Proof (By induction on $t$ ). Factor prices are equalized in the first period only if $W_{1} / R_{1}<\theta^{-1}(1-\theta) \min \left\{k_{1}, k_{1}^{*}\right\}$. Since preferences are homothetic, material balances imply that $\tilde{\sigma} W_{1}=P_{1,2}\left(\mu k_{2}+\mu^{*} k_{2}^{*}\right)$, where $W_{1}$ is the wage

\footnotetext{
${ }^{7}$ In other words, the diversification cone is the entire half-space of capital-labor ratios such that $k_{t}>\theta(1-\theta)^{-1} \omega_{t}$.
} 
in both countries. Using (8), the fact that $P_{1,2}=R_{1} / \beta$, and the expressions for the wage and rentals rates, one can derive

$$
\tilde{\sigma}(1-\theta) k_{1,1}=(\theta / \beta) \tilde{k}_{2},
$$

where $k_{1,1}$ is the capital-labor ratio in the first sector for both economies. Since $\tilde{k}_{2} / \tilde{k}_{1}=1-\delta+\beta\left(1-k_{1,1} / \tilde{k}_{1}\right)$, this expression implies a balanced growth path, with $G=\tilde{k}_{2} / \tilde{k}_{1}$ given by (12). Allocate investment so that $G=k_{2} / k_{1}=k_{2}^{*} / k_{1}^{*}$, and note that

$$
\begin{aligned}
W_{2} / R_{2} & =G W_{1} / R_{1}<G \theta^{-1}(1-\theta) \min \left\{k_{1}, k_{1}^{*}\right\} \\
& =\theta^{-1}(1-\theta) \min \left\{G k_{1}, G k_{1}^{*}\right\} .
\end{aligned}
$$

Hence, factor prices are equalized in period 2.

Now assume that factor prices are equalized in period $t$. Then $W_{t} / R_{t}<$ $\theta^{-1}(1-\theta) k_{t}$ and $\tilde{k}_{t+1} / \tilde{k}_{t}$ is given by (12). But then $W_{t+1} / R_{t+1}=G W_{t} / R_{t}$. Again, we can allocate investment so that $k_{t+1}=G k_{t}$ and $k_{t+1}^{*}=G k_{t}^{*}$. Hence, $W_{t+1} / R_{t+1}<\theta^{-1}(1-\theta) \min \left\{k_{t+1}, k_{t+1}^{*}\right\}$, which implies factor-price equalization in period $t+1$.

Since the investment good is traded, the equilibrium with factor-price equalization has a degree of static indeterminacy. I used this indeterminacy in the proof of Proposition 2, and it affects the definition of net foreign assets and thus the current account. Although the distribution of wealth, prices, and aggregate quantities are all tied down in equilibrium, the location of the capital stock in each period is not. I could just as well have described a cyclical allocation of the capital stock between countries as long as I kept each economy's installed capital-labor ratio in the diversification cones as the world economy grew.

Although the location of the capital stock can display cycles, its ergodic geographic distribution is determined because no country's installed capital stock can grow strictly more quickly than the world's capital stock for arbitrarily many periods. If if did, one country would be completely specialized in finite time, as the arguments leading to Proposition 1 established. But such a situation is inconsistent with a perfect foresight equilibrium since investment flows ensure that the returns on capital are equalized. Likewise, no country's installed capital stock can grow strictly more slowly than the world's capital stock for arbitrarily many periods. Hence, the current account is not determined from period to period, but its long-run average behavior is indeed well defined.

Proposition 2 and the analysis below assume that the installed capital stock in each period is proportional to the amount of labor located in each country. Thus there is no difference between the short-run and long-run behavior of the current account in such an equilibrium. The indeterminacy 
described above does not occur in a one-sector model with capital mobility because labor is a fixed factor. Equality of rental rates between countries ensures that capital is located in proportion to the workforce in each country. Thus the equilibria we examine in this paper are the natural analog of those in the Solow model, even though the two-sector model allows the relative price of investment to decline as a part of the development process.

Now consider the direction of trade in the integrated world equilibrium. Domestic exports per worker of the consumption good at time $t \geqslant 2$ are

$$
x_{t} \equiv k_{t, 1}^{\theta}-(1-\sigma) W_{t} / P_{t, 1}-\left(\sigma \Gamma / G^{1-\theta}\right) W_{t-1} / P_{t-1,1},
$$

where $I$ have used (10) and (11). Since $W_{t} / P_{t, 1}=\left(W_{t-1} / P_{t-1,1}\right) G^{\theta}, x_{t}=$ $\theta k_{t, 1}^{\theta}(1-\sigma / \tilde{\sigma})$. Hence, the home country exports the consumption good if and only if $\sigma<\tilde{\sigma}$. We have just established:

Proposition 3. The country with the higher savings rate imports the consumption good in period $t>1$.

Since the growth rate is increasing in the marginal propensity to save, (9) and (10) imply that the country with a lower savings rate has a higher autarkic interest rate. When the countries open for trade, the country with a lower interest rate experiences 'capital flight', as its residents acquire foreign assets in order to increase the return on their savings.

Gale (1974) describes a model in which the world economy converges to a steady state and shows two similar results: first, the rate of growth of the world economy reflects a weighted average of the savings propensities of the individual countries; and second, the country with a higher savings rate imports the consumption good in the long run. The intuition behind Gale's result is that the thrifty country will own a disproportionate share of the world stock of wealth in the long run. Since the steady state exhibits no further accumulation of net foreign assets, the country with a higher savings rate runs a trade deficit and consumes the proceeds of its rental income.

In a growing world economy, each country's share of world wealth remains constant. ${ }^{8}$ But, in each period, the country with a higher savings rate accumulates a disproportionate share of the change in the world capital stock per worker; hence, it runs a current account surplus. This implies that the thrifty country finances its imports of the consumption good in two ways: by exporting the investment good and by a surplus on interest income. In the language of balance-of-payments accounting, the country with the higher

\footnotetext{
${ }^{8}$ This fact contrasts sharply with capital accumulation in a model with infinitely lived agents such as those of Becker (1980) and Baxter (1992).
} 
savings rate may have a merchandise trade deficit, but this deficit is more than offset by the surplus on investment income from abroad.

For completeness, I state

Proposition 4. Assume that the two countries have identical preferences. Then the country with the higher capital-labor ratio exports the investment good in period $t=1$, and there is no net trade in period $t>1$.

Proof. Since $\sigma=\sigma^{*}, \tilde{\sigma}=\sigma$; hence, $x_{t}=0$ for all $t \geqslant 2$. Since the members of generation $t=1$ have identical preferences and factor prices are equalized, per capita demand for the consumption good is identical for all $h \in H_{1}$. Hence, for $t=1, x_{t}>0$ if and only if $k_{1}>k_{1}^{*}$, since agents $h \in H_{0}$ demand only the consumption good.

The capital-rich country exports the capital-intensive good in the first period if preferences are identical. This is the Heckscher-Ohlin theorem, and it shows that initial conditions for the world economy are actually 'level' effects, not growth effects. ${ }^{9}$ Proposition 4 suggests that one can think of exports of the investment good as analogous to the outflow of capital. Hence, the capital-rich country has a current account deficit and loss of net foreign assets, representing an adjustment of the stocks of capital and equalizing the rate of return on investment in the two countries. This occurs in the initial stage of the world economy.

The most striking implication of these propositions is that trade can reverse an autarkic growth trajectory. This result follows immediately from the observation that $\sigma$ may be such that the domestic economy will grow, but $\tilde{\sigma}$ may be sufficiently small so that the world economy will not grow. In particular a small thrifty economy may well export the investment good to a large spendthrift partner, thus precluding the possibility of growth.

Of course, the change in the growth rate resulting from opening an economy to trade influences both the wage rate and the interest rate. For agent in generation $t \geqslant 1$, the preferences described by (5) entail the indirect utility function:

$$
V\left(1+i_{t+1}, W_{t} / P_{t, 1}\right)=\left(W_{t} / P_{t, 1}\right)\left(1+i_{t+1}\right)^{\sigma} .
$$

Hence, an increase in the real wage or the interest rate raises the welfare of any such agent. Since the transition from autarky to free trade may harm a member of generation 0 in order to benefit members of later generations,

\footnotetext{
${ }^{9}$ Recall that I have assumed throughout the analysis that the installed capital stock in each period is proportional to the amount of labor in each country. Without this assumption the static indeterminacy discussed in the paragraph below Proposition 2 occurs here too.
} 
the autarkic path and that of free trade may not be Pareto ranked. However, since $1+i_{t+1}>0$ in any equilibrium, infinitely many agents will benefit from a transition to a higher growth rate, no matter what happens to the interest rate when an economy opens for trade.

\section{International economic policies and growth}

Assume now that each government can levy lump-sum taxes and transfers on the agents located in its economy. Let $b_{t}^{h}$ be such a transfer imposed by the domestic government at time $t$ on domestic $h \in H_{t-1} \cup H_{t}$. If $b_{t}^{h}<0$, then $h$ is taxed by her government, and if $b_{t}^{h}>0$, then $h$ receives a subsidy. The present value of the income of domestic $h \in H_{t}$ is now

$$
Y^{h}= \begin{cases}R_{1} K_{1} / L+P_{t, b} b_{1}^{h}, & \text { if } h \in H_{0}, \\ W_{t}+P_{t, b} b_{t}^{h}+P_{t+1, b} b_{t+1}^{h}, & \text { if } h \in H_{t}, \text { with } t \geqslant 1,\end{cases}
$$

where $P_{t, b}$ is the present price of the tax or subsidy imposed by the domestic government at time $t$. An analogous expression is true for foreign residents, with $P_{t, b^{*}}$ being the present price of taxes $b_{t}^{* h}$ levied abroad. I am using the formalism that the present price of these transfers need be defined in order to interpret them as receipts or taxes denominated in two different fiat assets in the discussion below.

I am now in a position to state an important result.

Theorem. Assume that preferences and technologies are such that one country will grow in an autarkic equilibrium. Then there is an international economic policy such that the world economy will grow.

Proof. If the world savings rate $\tilde{\sigma}$ is such that $G>1$, then the theorem is true using the policy $b_{1}^{h}=0$ for all domestic $h \in H_{0}$, and $\left(b_{t}^{h}, b_{t+1}^{h}\right)=(0,0)$ for all domestic $h \in H_{t}$ with $t \geqslant 1$, with the analogous trivial policy for foreign residents.

Now assume that $\tilde{\sigma}$ is such that the growth rate given in (12) satisfies $G \leqslant 1$. Without loss of generality, assume that the home country has a sufficiently high savings propensity so that it grows at rate $\bar{G}>1$ in autarky. Pick $G \in(1, \bar{G})$, and let $P_{t, b}=P_{t+1, b}=P_{b}$ and $P_{t, b^{*}}=P_{t+1, b^{*}}=P_{b^{*}}$, where $P_{b}$ and $P_{b^{*}}$ are strictly positive constants. Since the growth rate given in (12) is a continuous and monotonic function of $\tilde{\sigma}$, there is an $\alpha \in(0,1)$ such that a world economy consisting of proportions $\alpha=L /\left(L+L^{*}\right)$ of domestic agents and $\alpha^{*}=1-\alpha$ of foreign agents would grow at rate $G$.

Let $D_{t}$ be the set of domestic agents and $F_{t}$ be the set of foreign agents, 
both born at time $t$. Now consider an international economic policy such that $b_{1}^{h}=0$ for $h \in D_{0}, b_{1}^{* h}=0$ for $h \in F_{0}$, and

$$
\sum_{h \in D_{t}} P_{b}\left(b_{t}^{h}+b_{t+1}^{h}\right)=-\sum_{h \in F_{t}} P_{b^{*}}\left(b_{t}^{* h}+b_{t+1}^{* h}\right)>0
$$

for all $t \geqslant 1$. Since factor-price equalization occurs in the economy with no tax transfers and since this transfer lowers the initial wage-rentals ratio, factor prices will still be equalized. Thus for any $W_{t}=W_{l}^{*}$, we may choose $b_{t}^{h}+b_{t+1}^{h}$ so that the relative share of world income accruing to domestic residents in each period is $\alpha$.

In particular, let $W_{1}$ be the initial wage in a non-monetary economy growing at rate $G$. Then the monetary policy $b_{1}^{h}=0$ for $h \in D_{0}, b_{1}^{* h}=0$ for $h \in F_{0},\left(b_{t}^{h}, b_{t+1}^{h}\right)=\left(0,(\alpha-\mu)\left(W_{1} / \mu P_{b}\right)(G / \Gamma)^{t-1}\right)$ for $h \in D_{t}$ with $t \geqslant 1$, and $\left(b_{t}^{* h}, b_{t+1}^{* h}\right)=\left(0,\left(\alpha^{*}-\mu^{*}\right)\left(W_{1} / \mu^{*} P_{b^{*}}\right)(G / \Gamma)^{t-1}\right)$ for $h \in F_{t}$ with $t \geqslant 1$ will induce the necessary transfer. Moreover, the present value of each foreign agent's income is strictly positive. Hence, this policy supports an equilibrium such that the world economy grows at rate $G>1$.

The economic policy described in the theorem has at least two interpretations. The one I favor is that the theorem describes the distribution of seigniorage in the creation profiles of national debt. ${ }^{10}$ This interpretation implies that the two fiscal or monetary authorities cooperate. The surplus country expands aggregate demand, increases world growth, and lowers international interest rates. The deficit country absorbs the excess international reserves crcated by its trading partner in order to keep financial assets from 'crowding out' real international investment. Using the jargon of balance-of-payments accounting, we may say that the surplus country runs an expansionary policy, while its trading partner contracts and accumulates foreign exchange reserves. The theorem describes an economy where growth is accomplished by direct foreign investment, with the surplus country purchasing a share of the capital located abroad.

One could also interpret the policy described in the theorem as foreign aid. Direct transfers from a spendthrift donor to a thrifty recipient increase growth in both countries. Even though the two countries' marginal efficiencies of investment are identical, the propensity to save may be higher in the recipient country. Several initial generations in the donor country may be

\footnotetext{
${ }^{10}$ The fact that the present prices of the two assets are arbitrary positive constants is Kareken and Wallace's (1981) celebrated indeterminacy result. In the context of this paper, it shows that the rates of return (in terms of consumption foregone) of paper assets and of claims against capital are equalized. In earlier work (Fisher, 1990), I showed that these kinds of debt profiles can give rise to arbitrary transfers of resources between countries in exchange economies. I have also demonstrated that a positive stock of world debt crowds out real economic investment and slows the economy's underlying growth rate (Fisher, 1993).
} 
hurt by the tax, but the transfer will increase the real wage of infinitely many future generations in both countries.

The different interpretations of the theorem show that it describes, in essence, the effects of national aggregate demand on the growth rate of the world economy. I have been careful to analyze policies that neither distort intertemporal prices nor explicitly redistribute income between generations by running global generational surpluses or deficits. We may conclude that policies increasing aggregate demand in surplus countries without crowding out real economic investment have a positive effect on the growth rate of the world economy. This conclusion is general because the functional forms used above capture the asymptotic properties of a wide class of economies.

\section{Conclusion}

I have examined a model in which the growth rate of the world economy is influenced by economic policy. Analyzing lump-sum tax transfers makes it easy to find closed-form solutions describing the growth path of the world economy. Moreover, the policy described in the theorem induces efficient equilibrium allocations. Coordinated international policies allow governments to choose Pareto-optimal sequences of equilibrium allocations, and the role for policy in this model is quite different from the usual analysis of capital income taxation, with all its distortions in growing economies.

The reader might feel uncomfortable with my first interpretation of the policy in the theorem since it entails that some countries create a negative stock of national debt. It is more natural to think of a change in the status quo with positive stocks of debt in every country. Increasing the stock of any national debt slows down the rate of growth of the world economy and transfers resources from generations not yet born to those alive today. Such a policy may be Pareto-efficient, but giving resources to agents with low savings rates is a sure-fire way to slow world growth.

An important implication of this paper is that policies promote growth to the extent that they create seigniorage in countries where savings is encouraged. The specie-flow mechanism enforces exactly this kind of adjustment in a system of fixed exchange rates. Moreover, if we think of the instruments described in Section 5 as monetary policies, they are the only ones that redistribute resources from one country to another without crowding out real economic investment. This paper, then, has shown that the distribution of seigniorage in any international monetary system will affect world growth. Perhaps this observation will spur further interest in models of growth in which monetary or fiscal policy plays an explicit role. 


\section{References}

Baxter, M., 1992, Fiscal policy, specialization, and trade in the two-sector model: The return of Ricardo?, Journal of Political Economy 100, 713-744.

Becker, R.A., 1980, On the long-run steady state in a simple dynamic model of equilibrium with heterogeneous households, Quarterly Journal of Economics 95, 375-382.

De Long, J.B. and L. Summers, 1991, Equipment investment and economic growth, Quarterly Journal of Economics 106, 407-444.

Diamond, P.A., 1965, National debt in a neoclassical growth model, American Economic Review 55, 1126-1150.

Fisher, E.O'N., 1990, Sustainable balance of trade deficits, Journal of Monetary Economics 25, 411-430.

Fisher, E.O'N., 1992, Sustained growth in the model of overlapping generations, Journal of Economic Theory 58, 77-92.

Fisher, E.O'N., 1993, National debt and crowding out in a model of endogenous growth, unpublished manuscript, The Ohio State University.

Galc, D., 1971, Gencral equilibrium with imbalance of trade, Journal of International Economics 1, 141-158.

Gale, D., 1974, The trade imbalance story, Journal of International Economics 4, 119-137.

Grossman, G.M. and E. Helpman, 1989, Product development and international trade, Journal of Political Economy 97, 1261-1283.

Jones, L.E. and R. Manuelli, 1990, A convex model of equilibrium growth: Theory and policy implications, Journal of Political Economy 98, 1008-1038.

Jones, L.E. and R. Manuelli, 1992, Finite lifetimes and growth, Journal of Economic Theory $58,171-197$.

Kareken, J.H. and N. Wallace, 1981, On the indeterminacy of the equilibrium exchange rate, Quarterly Journal of Economics 96, 207-222.

Rebelo, S.T., 1991, Long-run policy analysis and long-run growth, Journal of Political Economy 99, 500-521.

Rivera-Batiz, L.A. and P. Romer, 1991, Economic integration and endogenous growth, Quarterly Journal of Economics 106, 531-556.

Young, A., 1991, Learning by doing and the dynamic effects of international trade, Quarterly Journal of Economics 106, 369-406. 